\title{
Nutritional Status of Children in Rural setting.
}

\author{
${ }^{1 .}$ George O. Boma, ${ }^{1}$ Ikiba Prosper Anthony, ${ }^{2}$ Mukoro Duke George, ${ }^{1}$ Ebiwari \\ Abaiola, ${ }^{1}$ Fiateide Andrew, ${ }^{1}$ McEteli D. Daniel, ${ }^{1}$ Tarimobo Rugina \\ Tarilanyo, ${ }^{3}$ Kalada Mefubara. \\ ${ }^{1 .}$ Colledge of Health sciences, Niger-Delta University. Amassoma, Bayelsa State, Nigeria. \\ ${ }^{2}$ Department of Accident and Emergency Medicine, Niger-Delta University Teaching Hospital, Okolobiri, \\ Bayelsa, Nigeria. \\ ${ }^{3}$ Department of Community Medicine, Colledge of Health Science, Niger-Delta University. Nigeria.
}

\begin{abstract}
:
Introduction: The fight against Malnutrition may remain for a long time as long as vast population in developing countries remain within the range of poverty coupled with on-going chaos from political instability in some developing nations. Therefore public health investigation of nutritional status of children is a continuous process that requires several re-assessments especially in volatile environment. Anthropometry is a direct method and the commonest method of assessment of nutritional status in children in these developing nations. Our study therefore assesses the nutritional status of children in rural setting in a developing nation as Nigeria and the influencing factors prevailing for the observed variations; The significant difference between the private and government pupils through their body mass index and other anthropometric parameters.

Method: A cross sectional survey of 191 children, aged 6-12 years were selected from local private and government school were used in the study. One of the private schools was randomly selected. The studied variables included; Age, sex of the pupils, religion of their parents, dietary pattern of the pupils and parents socio-economic status and educational background. Interview of pupils and parents was carried out using prepared questionnaire template. Research ethical clearance from the University, schools head, parent consent were obtained. Weight and height of the children were measured. Anthropometric indices were determined: Weight for height, weight for age, height for age and Body Mass Index (BMI). Data was analyzed using Microsoft excel, SPSS version 16 .The chi-square significance of association was determined at Level of significance less than 0.05 .
\end{abstract}

Results: The proportion of male student and female students are $50.8 \%$ and $49.2 \%$ respectively. A large proportion of fathers were Civil servants (12.6\%) while most mothers were farmers (17.3\%), the proportion of unemployed fathers $10.47 \%$ was more than unemployed mothers. $4.7 \%$. However more mothers that had no formal education (28.8\%) than the fathers $(9.4 \%)$. The proportion of female students (51.7\%) who were underweight were more than their male (48.3\%) counterparts. The proportion of male students (65\%) who were overweight was more than the females (35\%). Stunting was more prevalent amongst the males than their female counterparts. Collectively prevalence of stunting was $15.7 \%$, while prevalence of severe stunting was $5.23 \%$. Wasting was more prevalent amongst females 56.3\% than males 47.4\%. Most of the children diet consisted mainly of carbohydrates (98.4\%), while occasionally Protein (92.7\%), Fruit and Vegetable (95.8\%). Low socio-economical status, low educational background of parents, cultural norm and low protein diet influences the children's anthropometric parameters negatively and consequently their nutritional status. Other indirect indicators of the nutritional state of the children are the position of the child in the family, the school type attended by the child. Results showed that BMI does not indicate the specific type of under-nutrition compared to weight-height or weight for age.

Conclusion: The fight against malnutrition in developing nation by UNICEF therefore should be encourages and supported and public enlightenment campaign should be stepped -up.

\section{Introduction}

Nutritional status is an important index for measuring quality of life especially in children. In this respect, understanding the nutritional status of children has far reaching implications on better development of future generations. ${ }^{1}$ as well as future development of humanity. ${ }^{2}$

Health problems due to poor nutritional status in primary school-age children are among the most common causes of low school enrolment, high absenteeism, early dropout and unsatisfactory classroom performance. Primary school age (6-12 years) is a dynamic period of physical growth as well as of mental development of the child. ${ }^{1}$

Malnutrition in childhood was and is one of the reasons behind the high child mortality rates observed in developing countries. ${ }^{3,4}$ under nutrition is the most common type of malnutrition and the primary cause of ill 
health and premature mortality among children in developing countries and it is postulated that poverty and ignorance are primary causal factors of malnutrition in developing countries. ${ }^{5,}{ }^{6} \mathrm{Chronic}$ under nutrition in childhood is linked to slower cognitive development and serious health impairments later in life that reduce the quality of life of individuals. ${ }^{7}$

The world summit for children in 1990 in which 159 members participated agreed to end malnutrition and other health problems of children by the end of the decade. ${ }^{8} \mathrm{~A}$ child's entire life is determined in large measures by the food given to him or her during the first five years of life, under nutrition causes a great deal of physical and emotional suffering and food lack is a violation of a child's human rights. ${ }^{8}$ The direct methods are; Anthropometry, Biochemical, Clinical, and Dietary intake (mnemonic-ABCD).$^{9}$ It is widely accepted that for practical purposes, anthropometry is the most useful tool for assessing the nutritional status of children. ${ }^{10}$ There are many anthropometric indicators in use, such as mid arm circumference (MAC), weight for age, weight for height and body mass index (BMI) of Quetlet and triceps skin fold.

Children are classified into four categories; overweight (high weight for age), underweight (low weight for age), stunting (low height for age) or wasting (low weight for height). ${ }^{2}$ Low anthropometric values are those more than 2 standard deviations away from the standard set by Centre for disease control (CDC). ${ }^{7}$ Stunting is defined as a low height-for-age for children, and it measures the past (chronic) child under nutrition. Children with z-scores $<-2.00 \mathrm{SD}$ are said to be stunted and those $<-3.00 \mathrm{SD}$ severely stunted.

The nutritional status of children does not only directly reflect the socioeconomic status of the family and social wellbeing of the community, but also the efficiency of the health care system, and the influence of the surrounding environment. ${ }^{2}$

Bayelsa state is an oil producing state located in the oil rich Niger delta region, though an oil producing state, paradoxically the indigenes struggle with poverty in some of the communities with oil exploration and exploitation activities. Most staple foods are imported from neighboring states as food production and fishing (the main occupation in rural areas) have markedly reduced due to the deleterious effect of oil spillage on the soil and rivers.

The principal aim of the nutritional assessment of primary school children of the studied community was to map out the magnitude and distribution of malnutrition as a public health problem, to discover and analyze the factors that are directly or indirectly responsible and where possible to suggest appropriate corrective measures preferably capable of being applied with continuing community participation.

\section{Materials and Method}

The research was a descriptive cross-sectional and the population consisted primary school pupils in Okolobiri community. There are 3 primary schools (one public and two private primary schools) with a total of about 500 pupils. The study included the public and a private owned primary school. Pupils from primary one to primary six from each school who reside in Okolobiri are aged between 6-12 years were selected for this study.

\section{Exclusion criteria:}

Primary school pupils who do not reside at Okolobiri community, pupils who are below age 6 and above age 12 and pupils with skeletal deformities.

\section{Study Design}

The study was between October 2012 and December 2012.Two primary schools were selected for the study- the public and one private school ( Out of the two private primary schools). Simple random sampling balloting method was used to select one private schools. Students from primary one to six were used for the study, a sample size of 191 was calculated using a standard formula. Through a simple random sampling technique (balloting method) 131 pupils were selected from the public school while 60 pupils were selected from the private school. The studied variables included; Age, sex of the pupils, religion of their parents, dietary pattern of the pupils and parents socio- economic status.

Our minimum sample size was 191 . The sample size was determined using the formula: $\mathrm{n}=\mathrm{Z}^{2} \mathrm{PQ}$

$\mathrm{D}^{2} \quad$ Where: $\mathrm{n}=$ minimum sample size

$\mathrm{Z}=$ standard normal deviation set at 1.96 corresponding to $95 \%$ confidence level.

$\mathrm{P}=$ the prevalence of the malnutrition set at $87.4 \% \quad$ (Punjab, India) ${ }^{9}$

$$
\mathrm{Q}=1-\mathrm{p} ; \quad \mathrm{Q}=1-0.87=0.13 \mathrm{D}=0.05
$$
minimum size

Substituting the above values into the formula; $\mathrm{n}=(1.96)^{2} \times 0.87 \times 0.13=174$ +attrition $=191$ for

$$
(0.05)^{2}
$$

Data was collected by interviewing the participants using a pre-designed questionnaire, information obtained include: bio-data (age, sex, and religion), birth order, dietary assessment (24hour dietary recall, type of 
food eaten daily), and family size, parents/guardians occupation. Pupils in primary one and two were accompanied home and the questionnaire were administered to their parents/guardians.

Anthropometric parameters measured included; weight and height. Each child's height and weight was measured in the metric system, using standardized technique according to the standard anthropometric methods (international society for the advancement of kinathropometry (ISAK) (11). A measuring rod capable of measuring to an accuracy of $0.1 \mathrm{~cm}$ was used to assess height of the pupils in centimeters $(\mathrm{cm})$. The subject was made to stand against the wall without footwear with the feet parallel and with heels, buttocks, shoulders, and occiput touching the measuring rod, hands hanging by the sides. The head was held comfortably upright with the top of the head making firm contact with the horizontal head piece. Weight was measured after the height using a weighing scale measured to the nearest $0.1 \mathrm{~kg}$; the measurement was done with the pupils barefooted and with light underclothes only. Computed Z-scores of BMI for age, height for age and weight for age were then used to access thinness/overweight/obesity, stunting and wasting respectively using the WHO new reference values for school boys and girls.

Data was analyzed using Microsoft excel and SPSS version 16, chi-square was used for test of significance between variables like parents socioeconomic status, family type, number of siblings and prevalence of malnutrition $(\mathrm{p}<0.05)$ were considered statistically significant at a $95 \%$ confidence interval. The means of the anthropometric measurements were expressed in mean \pm sd. the descriptive values were expressed as percentages of the study population.

Ethical approval was from the College of Health sciences ethical committee; permission was obtained from head teachers of the respective schools and from parents/guardians.

Study Limitation: Financial constraints, Students absenteeism from schools, flooding of the community.

\section{Description Of Socio-Demographic Characteristics}

\section{Results:}

The research captured more students in the government school $68.6 \%$ than Private school $31.4 \%$.The proportion of male student and female students are $50.8 \%$ and $49.2 \%$ respectively.

As shown in table 1.0 below; Majority of the students were in Primary $3(22.0 \%)$ and their mean age was 8.8years, approximately 9years. Majority of them were from Monogamous families (65.4\%) and their birth order above the $2^{\text {nd }}$ position.

Table 1.0: Frequency Distribution Of The Student's Socio-Demographic Characteristics

\begin{tabular}{|c|c|c|c|c|c|c|}
\hline & $\begin{array}{l}\text { Male } \\
(\mathrm{n}=97)\end{array}$ & & $\begin{array}{l}\text { Female } \\
(n=94)\end{array}$ & & $\begin{array}{l}\text { Total } \\
(n=191)\end{array}$ & \\
\hline & $\mathrm{n}$ & $\%$ & $\mathrm{~N}$ & $\%$ & $\mathrm{~N}$ & $\%$ \\
\hline \multicolumn{7}{|l|}{ School } \\
\hline Government & 67 & $35.1 \%$ & 64 & $33.5 \%$ & 131 & $68.6 \%$ \\
\hline Private & 30 & $15.7 \%$ & 30 & $15.7 \%$ & 60 & $31.4 \%$ \\
\hline Gender & 97 & $50.8 \%$ & 94 & $49.2 \%$ & 191 & $100.0 \%$ \\
\hline \multicolumn{7}{|l|}{ Class } \\
\hline Pry 1 & 17 & $8.90 \%$ & 13 & $6.80 \%$ & 30 & $15.70 \%$ \\
\hline Pry 2 & 21 & $11.00 \%$ & 18 & $9.40 \%$ & 39 & $20.40 \%$ \\
\hline Pry 3 & 20 & $10.50 \%$ & 22 & $11.50 \%$ & 42 & $22.00 \%$ \\
\hline Pry 4 & 13 & $6.80 \%$ & 16 & $8.40 \%$ & 29 & $15.20 \%$ \\
\hline Pry 5 & 12 & $6.30 \%$ & 14 & $7.30 \%$ & 26 & $13.60 \%$ \\
\hline Pry 6 & 14 & $7.30 \%$ & 11 & $5.80 \%$ & 25 & $13.10 \%$ \\
\hline \multicolumn{7}{|l|}{ Age(years) } \\
\hline 6 & 13 & $6.80 \%$ & 8 & $4.20 \%$ & 21 & $11.00 \%$ \\
\hline 7 & 20 & $10.50 \%$ & 24 & $12.60 \%$ & 44 & $23.00 \%$ \\
\hline 8 & 17 & $8.90 \%$ & 17 & $8.90 \%$ & 34 & $17.80 \%$ \\
\hline 9 & 6 & $3.10 \%$ & 12 & $6.30 \%$ & 18 & $9.40 \%$ \\
\hline 10 & 15 & $7.90 \%$ & 15 & $7.90 \%$ & 30 & $15.70 \%$ \\
\hline 11 & 10 & $5.20 \%$ & 6 & $3.10 \%$ & 16 & $8.40 \%$ \\
\hline 12 & 16 & $8.40 \%$ & 12 & $6.30 \%$ & 28 & $14.70 \%$ \\
\hline Mean & $=8.8$ & SD & $=1.97$ & Min & $=6$ & $\operatorname{Max}=12$ \\
\hline \multicolumn{7}{|l|}{ Birth Order } \\
\hline $1^{\text {st }}$ & 21 & $11.00 \%$ & 17 & $8.90 \%$ & 38 & $19.90 \%$ \\
\hline $2^{\text {nd }}$ & 17 & $8.90 \%$ & 17 & $8.90 \%$ & 34 & $17.80 \%$ \\
\hline$>2^{\text {nd }}$ & 59 & $30.90 \%$ & 60 & $31.30 \%$ & 119 & $62.30 \%$ \\
\hline Mean & $=3.52$ & $\mathrm{SD}$ & $=2.305$ & Min & $=1$ & $\operatorname{Max}=12$ \\
\hline \multicolumn{7}{|l|}{ Type of Family } \\
\hline Monogamous & 66 & $34.60 \%$ & 59 & $30.90 \%$ & 125 & $65.40 \%$ \\
\hline Polygamous & 31 & $16.20 \%$ & 35 & $18.30 \%$ & 66 & $34.60 \%$ \\
\hline
\end{tabular}


As shown in table 2.0 below; a large proportion of fathers were Civil servants (12.6\%) while most mothers were farmers $(17.3 \%)$, the proportion of unemployed fathers $10.47 \%$ was higher than unemployed mothers. $4.7 \%$

Table 2.0: Frequency Distribution Of The Nutritional Enabling Factors

\begin{tabular}{|c|c|c|c|c|c|c|}
\hline \multirow[t]{2}{*}{ Enabling Factors } & \multicolumn{2}{|c|}{$\begin{array}{l}\text { Male } \\
(\mathbf{n}=97)\end{array}$} & \multicolumn{2}{|c|}{$\begin{array}{l}\text { Female } \\
(n=94)\end{array}$} & \multicolumn{2}{|c|}{$\begin{array}{l}\text { Total } \\
(\mathrm{n}=191)\end{array}$} \\
\hline & $\mathrm{N}$ & $\%$ & $\mathrm{~N}$ & $\%$ & $\mathrm{~N}$ & $\%$ \\
\hline \multicolumn{7}{|l|}{ Fathers occupation } \\
\hline Farmer & 13 & 6.80 & 18 & 9.40 & 31 & 16.20 \\
\hline Fisherman & 7 & 3.70 & 5 & 2.60 & 12 & 6.30 \\
\hline Trader & 10 & 5.20 & 6 & 3.10 & 16 & 8.40 \\
\hline Clergy & 3 & 1.60 & 4 & 2.10 & 7 & 3.70 \\
\hline Civil servant & 24 & 12.60 & 32 & 16.80 & 56 & 29.30 \\
\hline Unemployed & 12 & 12.40 & 8 & 8.50 & 20 & 10.47 \\
\hline Others & 20 & 20.90 & 29 & 15.20 & 49 & 36.10 \\
\hline \multicolumn{7}{|l|}{ Mothers occupation } \\
\hline Seamstress & 2 & 1.00 & 4 & 2.10 & 6 & 3.10 \\
\hline Farmer & 33 & 17.30 & 29 & 15.20 & 62 & 32.50 \\
\hline Fisher woman & 5 & 2.60 & 4 & 2.10 & 9 & 4.70 \\
\hline Trader & 30 & 15.70 & 29 & 15.20 & 59 & 30.90 \\
\hline servant & 8 & 4.20 & 9 & 4.70 & 17 & 8.90 \\
\hline unemployed & 4 & 4.12 & 5 & 5.31 & 9 & 4.71 \\
\hline Others & 10 & 10.3 & 19 & 20.2 & 29 & 15.2 \\
\hline
\end{tabular}

From table 3.0 below; Most fathers (63.6\%) have secondary level of education, while most mothers have primary level of education (46.6\%),0nly $2.6 \%$ mothers and $4.7 \%$ fathers had tertiary education the proportion of mothers that had no formal education $(28.8 \%)$ was higher than fathers $(9.4 \%)$ who had no formal education.

Table 3.0: Frequency Of The Nutritional Enabling Factors

\begin{tabular}{|c|c|c|c|c|c|c|}
\hline Educational status & Male & & Female & & Total & \\
\hline & $\mathrm{n}$ & $\%$ & $\mathrm{~N}$ & $\%$ & $\mathrm{~N}$ & $\%$ \\
\hline \multicolumn{7}{|l|}{$\begin{array}{l}\text { Father's educational } \\
\text { Status }\end{array}$} \\
\hline $\begin{array}{l}\text { No formal } \\
\text { education }\end{array}$ & 5 & $2.60 \%$ & 13 & $6.80 \%$ & 18 & $9.40 \%$ \\
\hline Primary & 28 & $14.70 \%$ & 19 & $9.90 \%$ & 47 & $24.60 \%$ \\
\hline Secondary & 61 & $31.90 \%$ & 56 & $29.30 \%$ & 117 & $61.30 \%$ \\
\hline Tertiary & 3 & $1.60 \%$ & 6 & $3.10 \%$ & 9 & $4.70 \%$ \\
\hline \multicolumn{7}{|l|}{$\begin{array}{l}\text { Mother's educational } \\
\text { Status }\end{array}$} \\
\hline $\begin{array}{l}\text { No formal } \\
\text { education }\end{array}$ & 23 & $12.00 \%$ & 32 & $16.80 \%$ & 55 & $28.80 \%$ \\
\hline Primary & 50 & $26.20 \%$ & 39 & $20.40 \%$ & 89 & $46.60 \%$ \\
\hline Secondary & 21 & $11.00 \%$ & 20 & $10.50 \%$ & 41 & $21.50 \%$ \\
\hline Tertiary & 3 & $1.60 \%$ & 2 & $1.00 \%$ & 5 & $2.60 \%$ \\
\hline
\end{tabular}

Figure 1:Nutritional classification of Children Using Body mass Index(BMI)

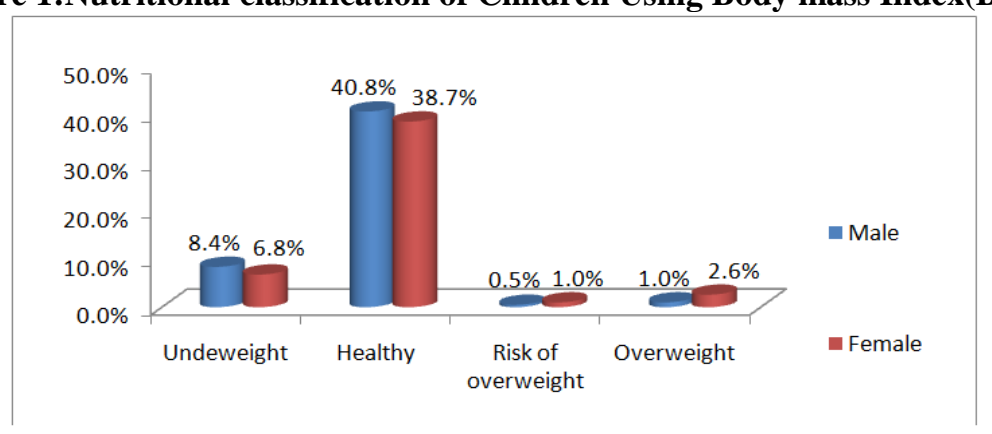


From Table 4.0 below, the proportion of female students $(51.7 \%)$ who were underweight were more than their male $(48.3 \%)$ counterparts. The proportion of male students $(65 \%)$ who were overweight was more than the females (35\%). Stunting was more prevalent amongst the males than their female counterparts. Collectively prevalence of stunting was $15.7 \%$, while prevalence of severe stunting was $5.23 \%$. Wasting was more prevalent amongst females $56.3 \%$ than males $47.4 \%$.

\begin{tabular}{|c|c|c|c|c|c|c|c|}
\hline \multicolumn{8}{|c|}{ For Age } \\
\hline & \multicolumn{2}{|l|}{ Male } & \multicolumn{2}{|c|}{ female } & \multicolumn{2}{|l|}{ Total } & \multirow[t]{2}{*}{ SCALE } \\
\hline & $\mathrm{N}$ & $\%$ & $\mathrm{~N}$ & $\%$ & $\mathrm{~N}$ & $\%$ & \\
\hline Underweight & 28 & 48.3 & 30 & 51.7 & 58 & 100 & WEIGHT-for-AGE SCALE \\
\hline TOTAL & $36.7 \%$ & & & & & & \\
\hline Stunting & 17 & 56.7 & 13 & 43.3 & 30 & 100 & HEIGHT-for-AGE SCALE \\
\hline TOTAL & $19.2 \%$ & & & & & & \\
\hline Severe & 5 & 50 & 5 & 50 & 10 & 100 & Height for age \\
\hline $\begin{array}{l}\text { Stunting } \\
\text { TOTAL. }\end{array}$ & $6.33 \%$ & & & & & & \\
\hline Wasting & 18 & 47.4 & 20 & 56.3 & 38 & 100 & Weight-for-height scale \\
\hline TOTAL & $24.1 \%$ & & & & & & \\
\hline
\end{tabular}

TABLE 5.0: Dietary PATTERN

As shown in table 5.0 below; diet consists mainly of carbohydrates (98.4\%), Most of the students occasionally consume Protein $(92.7 \%)$ and Fruit and Vegetable $(95.8 \%)$.

\begin{tabular}{lllllll}
\hline Dietary Pattern & \multicolumn{2}{l}{ Carbohydrate } & Protein & \multicolumn{3}{l}{ Fruit and Vegetable } \\
\hline \multirow{2}{*}{ Occasionally } & $\mathrm{N}$ & $\%$ & $\mathrm{n}$ & $\%$ & $\mathrm{n}$ & $\%$ \\
Regularly & 3 & 1.6 & 177 & 92.7 & 183 & 95.8 \\
Total & 188 & 98.4 & 14 & 7.3 & 8 & 4.2 \\
\hline
\end{tabular}

Table 6.0: Comparison Of Nutritional Staus Between Government And Private School Using Bmi For

Age.

The mean body mass index of students in government schools is $14.90 \mathrm{~kg} / \mathrm{m}^{2}$ and that of students in the private school is $15.82 \mathrm{~kg} / \mathrm{m}^{2}$. The student $\mathrm{t}$-value is 2.995 and the $\mathrm{P}$-value is $0.004(<0.05)$, this implies that there is a significant difference between the private and government students body mass index.

\begin{tabular}{llllll}
\hline School & N & Mean & Std. Deviation & t-value & P-value \\
\hline Government & 131 & 14.9094 & 1.37265 & 2.995 & $0.004(<0.05)$ \\
Private & 60 & 15.8155 & 2.86376 & & \\
\hline
\end{tabular}

\section{Discussion}

Our study showed a male to female ratio was a ratio of 1.03:1. It was however different from findings from work done in Bangalore were male to female ratio of $1.5: 1$ was found ${ }^{10.11}$. This shows that female education is fast gaining grounds and is a trend which should be encouraged.

The mean birth order was $3.5 \pm 2.3$ standard deviation. Although there was no statistical significance between birth order and nutritional status, a higher prevalence of underweight was observed amongst pupils who were the first and second children, $15.8 \%$ and $17.6 \%$ respectively compared to others whose birth order were above the second position $14.3 \%$ this is similar to findings in Indonesia were the prevalence of underweight was higher $25 \%$ amongst the first and second children compared to $18.1 \%$ observed in those who were third born and above ${ }^{12}$. Our finding contradicts work done in India were prevalence of underweight was higher in children with birth order greater than two ${ }^{13}$. This could be explained by the fact that younger children are better fed when compared to their older siblings. Majority of the pupils $65.4 \%$ were from monogamous families, while the rest were from polygamous families, this is similar to work done in Bangalore India were more pupils $55.4 \%$ were from monogamous families but differs from what was obtained in Bareilly, India were $73 \%$ of the pupils were from polygamous homes ${ }^{10,14}$. Although there was no statistical difference between the family type and nutritional 
status, we observed that the prevalence of underweight was higher (39.3\%) amongst children from polygamous homes were when compared to those from monogamous $18.4 \%$ it follows that more pupils $78.2 \%$ from monogamous families had healthy nutrition when compared to the $57.6 \%$ from polygamous families. This is similar to work done in Abeokuta, Nigeria and Brailley ${ }^{14,15}$. This shows that the type of family has a major influence on the nutritional status of children. Similar to the finding among under-five children by Ojofeitimi et al, the prevalence of stunting was higher among children from polygamous homes. Polygamy is a common family-setting among Africans, particularly those from the lower socioeconomic group. It usually has a larger number of people compared to monogamous homes ${ }^{16}$. The larger the number of people in a home the smaller the amount of food that gets to children, especially in the poorest families ${ }^{13}$. There is also the possible risk of overcrowding. This could lead to the spread of diseases, such as acute respiratory infections and diarrhea which are known to lead to malnutrition ${ }^{15}$. It is therefore, not surprising that stunting occurred more commonly among children from polygamous families compared to children from monogamous families.

Parents' occupation: most of our pupils mothers $(32.5 \%)$ were farmers, while $30.9 \%$ were petty traders, only $18.9 \%$ were civil servants with regular income, this is different from study done in Kaduna were most mothers were civil servants ${ }^{13}$.

It was observed that prevalence of underweight was higher amongst pupils whose parents were unemployed $(66.7 \%)$ amongst pupils whose mothers were unemployed and $60 \%$ amongst pupils whose fathers were unemployed.) this is in keeping with findings elsewhere ${ }^{12,14,17}$ and goes to show that economically empowered parents provide better nutrition and health for their offsprings. Ahmed confirmed that better economic situation can be a primary cause for better growth of school children because economic situation usually influences the kind and quantity of food consumed ${ }^{18}$.Most fathers $(63.6 \%)$ had secondary level of education, while most mothers had primary level of education $(46.6 \%)$ this could explain the low prevalence of under nutrition seen in our study as compared to other studies ${ }^{12,14,19}$. Concerning educational status; the mothers' education plays a major role in determining the nutritional status of children ${ }^{14,19}$.In agreement with most studies low maternal education is a major determinant of malnutrition ${ }^{13,16}$.

The overall prevalence of underweight $36.7 \%$, proportion of female students $(51.7 \%)$ who are underweight are more than their male(48.3\%) counterparts. The rate was lower compared to studies from Assam, India and Pakistan were overall prevalence of underweight was as high as $51.7 \%$ and $46.4 \%$ respectively ${ }^{20.21}$. Ijarotimi et al at Akure ${ }^{22}$ ascribed the disparity between the male and female child that males are better fed than their female siblings, the "lions share" of the meat/fish will always go to the males. Collectively prevalence of stunting from our study was $19.2 \%$, result was low compared to studies from Akure Lagos, andMarkurdi ${ }^{5,22,23}$ however slightly higher than what was obtained at Abeokuta were prevalence was $16.7 \%$. Stunting was more prevalent among the males $56.7 \%$ than their female counterparts $43.3 \%$, this is consistent with other works ${ }^{15,19,22,24}$, but differ from the other findings among school children which revealed that more girls had poorer health or were wasted and stunted than the boys ${ }^{25}$. Overall prevalence of severe stunting was $6.33 \%$, this is slightly higher than $4.98 \%$ and $5.23 \%$ reported in North Bengal, India and Turkey respectively ${ }^{26,27}$. It was however lower than findings in Abeokuta were prevalence of severe stunting was $22.2 \%$ 15. Equal prevalence was observed amongst males (50\%) and females $(50 \%)$ collectively, this was different from what was obtained in Indonesia were prevalence of severe stunting was higher amongst males than females ${ }^{12}$.The Prevalence of wasting was $24.1 \%$, this was higher than what was obtained in Osun state and Jos, This difference could be attributed to the recent flooding which displaced many families and thus affected their nutritional status. Wasting was more amongst females $56.3 \%$ than males $47.4 \%$ contrary to findings elsewhere $^{20,24}$ Using BMI for age; $79.6 \%$ of pupils have normal/healthy nutritional status with a slight male preponderance of $40.8 \%$ over their female counterparts $(38.7 \%)$. The results showed that the use of BMI as indicator for children does not provide a true and detail picture of the nutritional status of these children. The prevalence of overweight $(1.6 \%)$ and obesity $(3.7 \%)$ in our study was low when compared with children in developed countries ${ }^{28}$.The reasonable cause is that high calorie food which are hardly affordable. Another plausible explanation is that the Nigerian children may have been engaged in more physically demanding activities compared to their contemporaries in developed countries. Majority of the children walk to school daily regardless of the distance and this may have enhanced their physical activity level ${ }^{28}$. In the community were our work was done, most of the mothers are farmers and most children accompany their mothers to the farm and partake in farming activities. Our results showed that majority of the students consumed carbohydrate diets as compared to proteins, fruits and vegetables; this is similar to what was obtained in some other studies $12,21,22$, the reason for this could be due to the high cost of protein rich foods, fruits and vegetables are not commonly produced here but are supplied from neighboring states which make them quite expensive. The mean body mass index of students in government schools was $14.90 \mathrm{~kg} / \mathrm{m}^{2}$ and that for the private school was $15.82 \mathrm{~kg} / \mathrm{m}^{2}$, and this was statistically significant. This is similar to other works were it was also reported that students from private schools had healthier nutrition when compared to their counterparts from public schools ${ }^{19,29}$. The reason for this difference could be explained by the fact that students that attend private schools tend to come from richer 
homes with better food security. The type of school a child attends maybe a pointer to the socioeconomic status of the parents and invariably affects the food intake of the child ${ }^{30}$.

\section{Conclusion}

Malnutrition is still common findings in developing countries. Most common is the under nutrition rather than overnutrition. Better measurements for nutritional status for children was weight for age, height and height for age rather than BMI. Several factors enable the poor nutritional status of children directly such as low socio-economical status and poor educational background of their parents as well as low protein diets . Other indirect indicators of the nutritional state of the children are the position of the child in the family, the school type attended by the child. The fight against malnutrition in developing nation by UNICEF therefore should be encourages and public enlightenment campaign should be stepped -up.

\section{Reference}

[1] AnurageS.,SyedE.M.Payal M.S. Bhushan K.:Nutritional status of school aged children-A scenario of Urban slums in India: Archives of public health 2012,70:8

[2] World Health Organization: Research to improve implementation and effectiveness of school health programmes. Geneva: WHO; $1996,1,9-15$.

[3] UNICEF policy review: Strategy for improved nutrition of children and women in developing countries. UNICEF, New york: USA; 1990:5-36

[4] World Health Organization Expert Committee: An estimate for the prevalence of child malnutrition in developing countries. World Health Stat Q 1985, 38:331-347.

[5] Abidoye RO, Ihebuzor NN: Assessment of nutritional status using anthropometric methods on 1-4 year old children in an urban ghetto in Lagos, Nigeria. Nutritional health 2001, 15:29-39.

[6] Odunayo SI, Oyewole AO: Risk factors for malnutrition amongst rural Nigerian children. Asia Pacific journal. Clinical nutrition 2006, 15:491-495.

[7] Nutrition for the school aged child(2002), Nebguide services:G92:1086A

[8] World Health organization report; life in the $21^{\text {st }}$ century; a vision for all. Geneva: WHO; 1998.

[9] Water low IC, Buzina R, Keller W, Lane IM, Tanner IM; The presentation and use of height and weight for comparing the nutritional status of groups of children under the age of 10 years. Bull WHO 1977,55:489-498

[10] Hassan I, Mond Abdul HA; an assessment of nutritional status of the children of government Urdu higher primary schools of Azad Nagar and its surrounding areas of Bangalore: Archives of applied science research, 2011, 3(3):167-176.

[11] Olumuyiwa S. falade, Israel Otemuyiwa, oluwemimoOluwasola, Wale Oladipo, Steve A. Adewusi. The nutritional status of pupils in a public primary school in Ile-Ife, Osun State, Nigeria; food and nutrition sciences; 2012:3(596-605).

[12] Badrialaily M.: Nutritional status and related factors among elementary school students in Banda Aceh Municipality, Nanggroe Province, Indonesia. 2008; 23 -28.

[13] Rowland M.G.M: Prevention of protein energy malnutrition; Diseases of children in the tropics and subtropics. Fourth edition, Kent, 1999: 358-366.

[14] Srivastava A. Mahmood S.E, Srivastava P.M: Nutritional status of school-age children-A scenario of urban slums in India; Archives of public health; 2012:70(8).

[15] Sebanjo O., Oshikoya K. A.,Odusanya O.O. . Njokanma O. F.: Prevalence of and Risk factors for stunting among school children and Adolescents in Abeokuta, SouthWest Nigeria; Journal Health population nutrition; 2011;4(364-370).

[16] Ojofeitimi E.O, Owolabi O.O, Aderounmu A, Esimai A.O, Alasanmi S.O: A study on under five nutritional status and its determinants in a semi-rural community of Ile-Ife, Osun State, Nigeria: Nutritional Health 2003; 17: 21-27.

[17] Hassan A., Onabanjo O.O., Oguntona C.R.B: Nutritional Assessment of school age children attending conventional primary and integrated quranic schools in Kaduna; Research journal of Medical sciences, 2012:6(4):187-192.

[18] Ahmed F. Bhuyan, A.H; Shaheen N. Baruas; Margghs, B.M and jackson A. effect of sociodemographic conditions and growth of urban school children of Bangledesh. European journal of clinical nutrition 1991;45: 327-330,

[19] Olusoga O.J, R.S Abisola, C.S Oluwakemi:Evaluation of the nutritional status of primary one pupils in Abeokuta South Local Government Area of Ogun State, Nigeria: Research journal of medical Sciences; 2008:2(2): 61-64.

[20] MedhiG.K., BaruaA. and Mahanta J.: Growth and Nutritional status of school age children (6-14years) of tea Garden Workers of Assam; journal of Human ecology; 2006:19(2):83-85.

[21] Anwar H.N, Muhammad I.Z, Hussein S.: Health screening of primary school children; a case study of district Sargodha, Pakistan. Pakistan Journal of social sciences, 2006:4(1-2):40-47.

[22] Ijarotimi O.S, Odeyemi A. O.: Prevalence of food insecurity among rural communities and its effects on nutritional status of children (8-15 years) in Ondo state, Nigeria. Journal of medicine and medical sciences; vol 3(10); 005-015, 2012.

[23] Daniel T .G, Toriola A. L., Shaw B. S., Lateef O A., Monyeki M. A, Akinyemi O. and Alabi O. A.: Anthropometrically determined nutritional status of urban primary school children in Markudi, Nigeria. Bmc public health; 2011;11(769).

[24] Zalilah M.S., Jenny T.B., Nan E.J: Nutritional status of primary school children from low income households in Kuala Lumpur: Medical Journal of malnutrition; 2000;6(17-32).

[25] Ukoli F.A.,Nwankwo M.O.,: Nutritional status of urban Nigerian school children relative to NCHS reference population, East African Medical Journal; 2000:7(9),409-413.

[26] Mama P.K., Debasis D., Bera T.K.,: Anthropometric assessment of physical growth and nutritional status among school children of North Bengal;Anthropologist; 2011:13(4):299-305,.

[27] Gur E., Can G.: Is undernutrition a problem among Turkish school Children? Journal of tropical paediatrics; 2006:52(421-426).

[28] Annik s. , Leon F.: What is the relationship between child nutrition and school outcomes? 2006.

[29] Fusto J.C: U urban-rural differentials in child malnutrition: trends and socioeconomic correlates in sub Saharan Africa; Health place 2007; 13(1):205-223.

[30] Charles D, Delisle H. F and Receveur O.,: Poor nutritional status of school children in urban and peri urban areas of Ouagadougou (Burkinafaso):nutritional journal 2011:10(34). 